\title{
Morphological Comparison of Five Varieties of Colocasia esculenta (L.) Schott in Anambra State, Southeastern Nigeria
}

\author{
Chinelo A. Ezeabara*, C. U. Okeke, J. E. Amadi, A. I. Izundu, Bibian O. Aziagba, P. T. Egboka, \\ C. D. Udechukwu \\ Department of Botany, Nnamdi Azikiwe University, Awka, Nigeria \\ Email: "e.chinelo5@yahoo.com
}

Received 23 September 2015; accepted 8 November 2015; published 12 November 2015

Copyright (C) 2015 by authors and Scientific Research Publishing Inc.

This work is licensed under the Creative Commons Attribution International License (CC BY). http://creativecommons.org/licenses/by/4.0/

(c) (i) Open Access

\begin{abstract}
Comparative morphological study of five varieties of Colocasia esculenta (L.) Schott present in Anambra State, Nigeria was carried out, in order to furnish plant taxonomists with information which could be of great help in delimitation of the varieties. Significant difference was established at $p<0.05$. The result showed that adaxial surface of "kochuo" had a purplish dot on the centre, abaxial leaf surface had a conspicuous purplish colour at the point of attachment to the leaf, and the cormels had numerous striking vertical purple stripes on the surface. There was presence of foliaceous (leaf-like) appendages at the veins of the abaxial surface of the leaf of "ogeriobosi". The leaf length ranged from $35.6 \pm 7.70 \mathrm{~cm}$ ("kochuo") to $49.9 \pm 3.55 \mathrm{~cm}$ ("ogeriobosi"). Petiole length of "ogeriobosi" was the highest $(63.3 \pm 3.83 \mathrm{~cm})$, whereas the least was Colocasia esculenta var. antiquorum $(26.67 \pm 2.20 \mathrm{~cm})$. The corm length ranged from $4.10 \pm 0.10 \mathrm{~cm}$ (Colocasia esculenta var. antiquorum) to $8.60 \pm 0.35 \mathrm{~cm}$ ("ogeriobosi"), while the cormel length ranged from $3.70 \pm 0.96 \mathrm{~cm}$ (Colocasia esculenta var. antiquorum) to $7.03 \pm 0.36 \mathrm{~cm}$ ("ogeriobosi"). This work has revealed diagnostic and differential morphological characters, which could be useful for identification and description of varieties of $C$. esculenta. In addition, it provided additional information which might be helpful in resolving the on-going controversy in the taxonomy of Colocasia, which would, in turn, probably lead to possible delimitation of $C$. esculenta.
\end{abstract}

\section{Keywords}

Colocasia, Corms, Cormels, Diagnostic Characters, Foliaceous Appendages, Morphological Characters, Plant Taxonomy

\footnotetext{
*Corresponding author.
}

How to cite this paper: Ezeabara, C.A., Okeke, C.U., Amadi, J.E., Izundu, A.I., Aziagba, B.O., Egboka, P.T. and Udechukwu, C.D. (2015) Morphological Comparison of Five Varieties of Colocasia esculenta (L.) Schott in Anambra State, Southeastern Nigeria. American Journal of Plant Sciences, 6, 2819-2825. http://dx.doi.org/10.4236/ajps.2015.618278 


\section{Introduction}

Colocasia esculenta (L.) Schott of the family Araceae are popular tuber crops in Southeastern Nigeria. Colocasia esculenta and Xanthosoma sagittifolium serve as staple food in Southeastern Nigeria, and are commonly known as cocoyam. Various ethnic groups in Nigeria have different names for C. esculenta, which attested to its nationwide distribution and use. It is known as ede/akaso/uli in Ibo, guaza in Hausa, koko in Yoruba, mkpon in Efik and ikereburu in Ijo [1]-[4].

The observed varieties of $C$. esculenta showed a lot of variability in morphological characters. This variability is common among crops that have been cultivated for a long time [5]. Currently, C. esculenta is considered as the major species with two varieties: Colocasia esculenta var. antiquorum (L.) (Schott) Hubbard \& Rehder and Colocasia esculenta var. esculenta (L.) Schott [2] [6].

The knowledge of variability of $C$. esculenta is deficient and limited. In addition, there is paucity of literature on its taxonomy, which implies that thorough taxonomic research has not been done on $C$. esculenta. As a result, a morphological study on varieties of $C$. esculenta becomes a necessity; because morphological characters are the strongest tools used in taxonomic classification of plants, and this makes its application very crucial. The objective of this work, therefore, is to investigate the morphology of varieties of $C$. esculenta, with a view to exploring the macro-characters, which are the major criterion for plant classification.

\section{Materials and Methods}

\subsection{Sources of Materials}

Cormels of varieties of $C$. esculenta were obtained from the local farmers from the three senatorial districts in Anambra State, namely: Agulu in Anaocha LGA (Anambra North); Umuikwu-Anam in Anambra West LGA (Anambra Central) and Uga in Aguata LGA (Anambra South).

Five varieties were then selected from the three senatorial districts and grown in a common garden at Uga, Anambra State, Nigeria in June, 2013. They include Colocasia esculenta var. antiquorum (eddoe), Colocasia esculenta var. esculenta (dasheen), "Kochuo", "Nwine" and "Ogeriobosi” with collection numbers: ACE 34, ACE 35, ACE 36, ACE 37 and ACE 38, respectively. The voucher specimens were authenticated by Prof. C. U. Okeke and C. A. Ezeabara, Plant Taxonomists, and deposited in herbarium of Department of Botany, Nnamdi Azikiwe University, Awka, Anambra State, Nigeria.

\subsection{Morphological Study}

The petiole and leaf measurements were done in October 2013; hence the plants were four months old when the measurements were done. The corm (main stem) and cormels were measured in December 2013. The meristem of the corm (main stem) were removed until they cannot be removed without force; third cormels from the base of the main stem were randomly chosen and third fully opened active leaves and petioles from the base were measured. The petiole measurement started from the ligule to the base of the leaf. The raw corms and third cormels from the base of the main stem were peeled with a knife. Observations and measurements of the plants parts were done using eye lens, thread and ruler. Photographs of the habit and plant parts were taken with digital camera (Sony DSC-W230, China).

\subsection{Statistical Analysis}

One-Way-Anova (F-Test) was used to analyze the data at $\mathrm{p}<0.05$. Duncan’s Multiple Range Test (DMRT) was then used to separate the means and data were expressed as mean \pm standard deviation of triplicate determinations.

\section{Results}

The leaf of all the varieties was thick, succulent and downward-pointing, with reticulate venation. Three strong midribs arose from the point of attachment to the petiole, the main midrib pointed towards the basal lobe, while other two smaller midribs extended to the two posterior lobes, with one midrib on each lobe. The primary lateral veins originated from the three midribs, while the veinlets emanated from these primary lateral veins. The leaf margin was entire; the leaf blade was sagittate and not shiny, the abaxial and adaxial surfaces of the leaf blade 
were glabrous with the exception of abaxial surface of "ogeriobosi”; the anterior lobes were twice as large as the posterior lobes, which were round in shape; and the petiole attachment was peltate. Petiole had a wide range of colours, including pale green, dark green, yellowish green and purple (Figures 1(a)-(j)). The base of petiole of C. esculenta var. antiquorum was deep purple (Figure 1(a)) when compared with C. esculenta var. esculenta (Figure 1(b)). The leaf of "kochuo" has a prominent distinctive feature, which was presence of a purplish dot on the centre of the adaxial surface (Figure 1(c)). The petiole of "nwine" was yellowish green (Figure 1(d), Figure 1(i) and Table 1), while that of "ogeriobosi" was purple in colour (Figur 1(e) and Table 1). Abaxial leaf surface of "kochuo" had a conspicuous purplish colour at the point of attachment to the leaf (Figure 1(h)). "Ogeriobosi" had foliaceous (leaf- like) appendages at the veins of the abaxial surface of the leaf (Figure 1(j)).

C. esculenta var. antiquorum and "kochuo" had large corms which were more or less orbicular (approximately circular) in shape, whereas corms of C. esculenta var. esculenta, "nwine" and "ogeriobosi" were more or less oval. "Ogeriobosi" had the largest corm as well as the largest cylindrical cormels (Figures 2(a)-(f)). "Nwine" possessed large corm with slender cormels (Figure 2(c) and Figure 2(f)). Cormels of C. esculenta var. antiquorum were small, numerous and round. They were relatively the smallest, whereas those of "ogeriobosi" were the biggest (Figure 2(a), Figure 2(e), Figure 2(f) and Table 1). The cormels of $C$. esculenta var. esculenta were few and more or less cylindrical shaped, while cormels of "kochuo" were numerous with vertical purplish stripes on the surface.

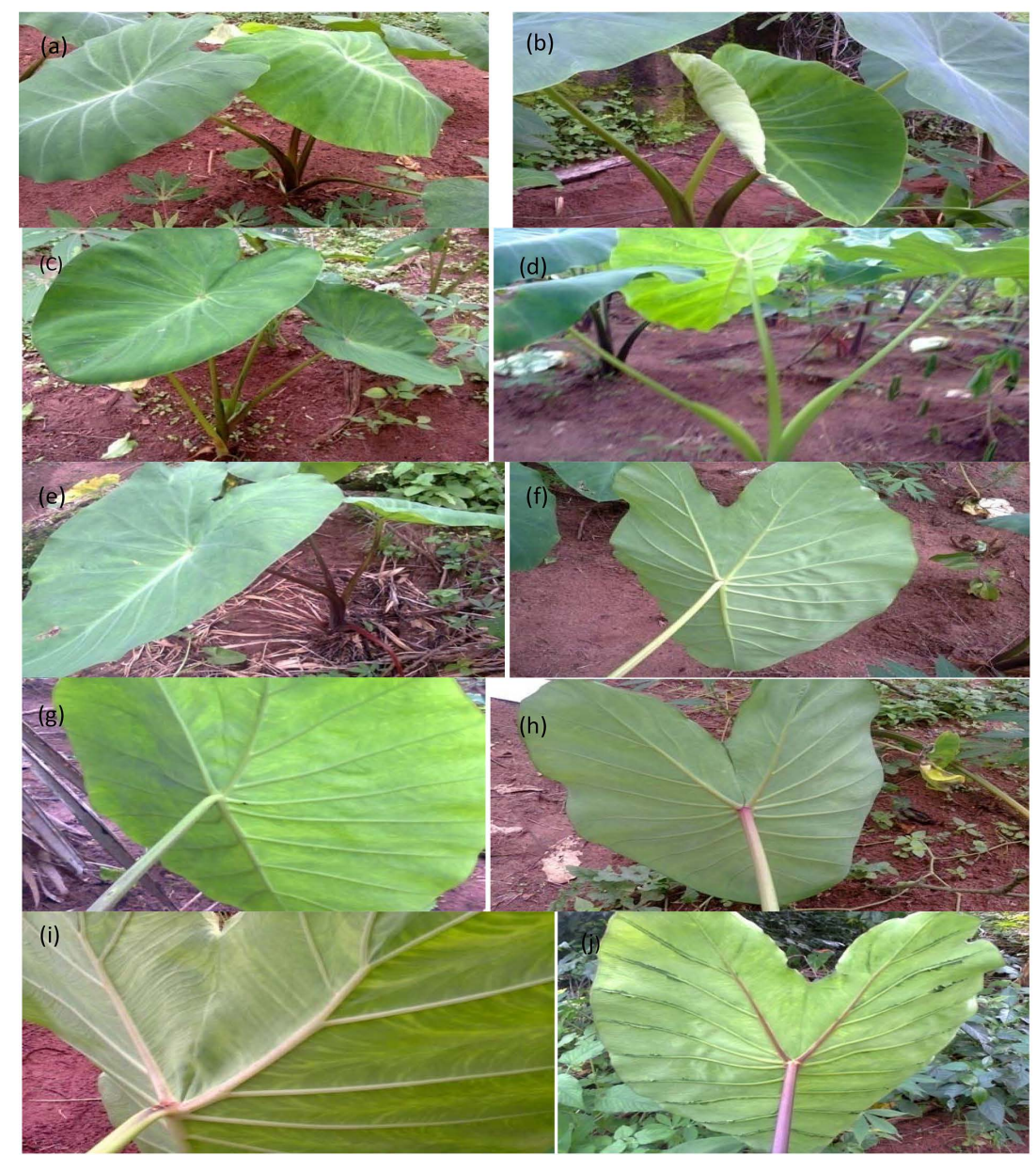

Figure 1. Photomicrographs of habit and abaxial leaf surfaces of five varieties of Colocasia esculenta. (a) Habit of C. esculenta var. antiquorum. (b) Habit of C. esculenta var. esculenta. (c) Habit of "kochuo". (d) Habit of "nwine". (e) Habit of "ogeriobosi”. (f) Abaxial leaf surface of C. esculenta var. antiquorum. (g) Abaxial leaf surface of C. esculenta var. esculenta. (h) Abaxial leaf surface of 'kochuo'. (i) Abaxial leaf surface of "nwine". (j) Abaxial leaf surface of "ogeriobosi”. 


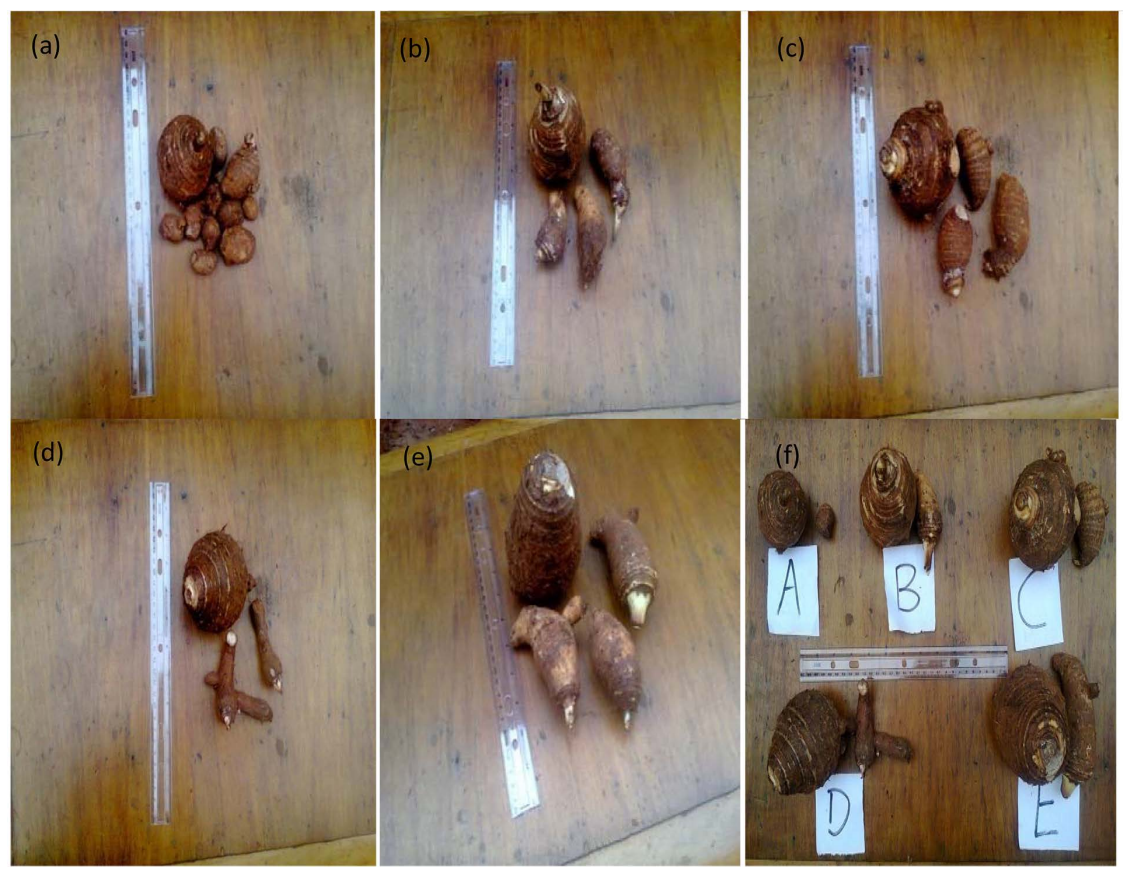

Figure 2. Photomicrographs of five varieties of Colocasia esculenta showing the shape, size and texture of the main stem (corm) and cormels. (a) C. esculenta var. antiquorum. (b) C. esculenta var. esculenta. (c) "kochuo". (d) "nwine". (e) "ogeriobosi”. (f) [(A) C. esculenta var. antiquorum, (B) C. esculenta var. esculenta, (C) "kochuo", (D) "nwine", (E) “ogeriobosi”].

Table 1. Morphological characters (cm) of Colocasia esculenta var. antiquorum, Colocasia esculenta var. esculenta, "Kochuo", "Nwine” and "Ogeriobosi”.

\begin{tabular}{ccccccccccc}
\hline Varieties & Petiole length Petiole colour & $\begin{array}{c}\text { Leaf } \\
\text { length }\end{array}$ & $\begin{array}{c}\text { Leaf } \\
\text { width }\end{array}$ & $\begin{array}{c}\text { Leaf } \\
\text { colour }\end{array}$ & $\begin{array}{c}\text { Corm } \\
\text { length }\end{array}$ & $\begin{array}{c}\text { Corm } \\
\text { width }\end{array}$ & $\begin{array}{c}\text { Cormel } \\
\text { length }\end{array}$ & $\begin{array}{c}\text { Peeled } \\
\text { tuber } \\
\text { (raw) }\end{array}$ \\
\hline Antiq & $26.67 \pm 2.20^{\mathrm{a}}$ & Pale green & $42.80 \pm 5.86^{\mathrm{a}}$ & $36.90 \pm 4.25^{\mathrm{a}}$ & $\begin{array}{c}\text { Pale } \\
\text { green }\end{array}$ & $4.10 \pm 0.10^{\mathrm{a}}$ & $5.23 \pm 1.28^{\mathrm{a}}$ & $3.70 \pm 0.96^{\mathrm{a}}$ & Green \\
Esc & $38.07 \pm 2.22^{\mathrm{b}}$ & Pale green & $44.80 \pm 4.33^{\mathrm{b}}$ & $36.00 \pm 2.65^{\mathrm{a}}$ & $\begin{array}{c}\text { Deep } \\
\text { green }\end{array}$ & $6.17 \pm 0.50^{\mathrm{b}}$ & $4.47 \pm 0.72^{\mathrm{b}}$ & $5.00 \pm 1.35^{\mathrm{b}}$ & Green \\
“Kochuo" & $40.33 \pm 22.35^{\mathrm{c}}$ & Green & $35.6 \pm 7.70^{\mathrm{c}}$ & $34.13 \pm 4.80^{\mathrm{b}}$ & $\begin{array}{c}\text { Deep } \\
\text { green }\end{array}$ & $4.86 \pm 1.95^{\mathrm{c}}$ & $6.33 \pm 1.27^{\mathrm{c}}$ & $5.45 \pm 3.02^{\mathrm{c}}$ & Purple \\
"Nwine” & $41.4 \pm 5.65^{\mathrm{d}}$ & $\begin{array}{c}\text { Yellowish } \\
\text { green }\end{array}$ & $41.4 \pm 4.23^{\mathrm{d}}$ & $45.27 \pm 3.66^{\mathrm{c}}$ & $\begin{array}{c}\text { Pale } \\
\text { green }\end{array}$ & $4.55 \pm 0.87^{\mathrm{d}}$ & $5.67 \pm 0.59^{\mathrm{d}}$ & $6.63 \pm 1.42^{\mathrm{d}}$ & Pink \\
“Ogeriobosi” & $63.3 \pm 3.83^{\mathrm{e}}$ & Purple & $49.9 \pm 3.55^{\mathrm{e}}$ & $35.8 \pm 3.64^{\mathrm{d}}$ & $\begin{array}{c}\text { Deep } \\
\text { green }\end{array}$ & $8.60 \pm 0.35^{\mathrm{e}}$ & $5.53 \pm 0.76^{\mathrm{e}}$ & $7.03 \pm 0.36^{\mathrm{e}}$ & Milk \\
\hline
\end{tabular}

Antiq = Colocasia esculenta var. antiquorum; Esc = Colocasia esculenta var. esculenta . Data are means \pm standard deviation of triplicate determinations. Columns with different subscripts are significantly different at $(\mathrm{p}<0.05)$.

There was significant difference among the petiole length of all the varieties at $\mathrm{p}<0.05$. Petiole length of "ogeriobosi" was the highest $(63.3 \pm 3.83 \mathrm{~cm})$, while the least was $C$. esculenta var. antiquorum $(26.67 \pm 2.20$ $\mathrm{cm})$. The petiole colour of $C$. esculenta var. antiquorum and C. esculenta var. esculenta were the same, whereas others differed. There was significant difference among the leaf length of all the varieties at $p<0.05$. The leaf length of "ogeriobosi" was the highest $(49.9 \pm 3.55 \mathrm{~cm})$, while the least was "kochuo" $(35.6 \pm 7.70 \mathrm{~cm})$. There was no significant difference between the leaf width of $C$. esculenta var. antiquorum $(36.90 \pm 4.25 \mathrm{~cm})$ and $C$. esculenta var. esculenta $(36.00 \pm 2.65 \mathrm{~cm})$, whereas the leaf width of "nwine" $(45.27 \pm 3.66 \mathrm{~cm})$ was the highest. The leaves of C. esculenta var. esculenta, "kochuo" and "ogeriobosi" were deep green in colour, while those of C. esculenta var. antiquorum and "nwine" were light green. There was significant difference among the corm 
lengths of all the varieties. The highest corm length was $8.60 \pm 0.35 \mathrm{~cm}$ (“ogeriobosi”), and the least was $4.10 \pm$ 0.10 (C. esculenta var. antiquorum). There was also significant difference among the corms width of all the varieties. "Kochuo" $(6.33 \pm 1.27 \mathrm{~cm})$ had the greatest corm width, whereas the least was found in C. esculenta var. esculenta $(4.47 \pm 0.72 \mathrm{~cm})$. The cormel length of "ogeriobosi” $(7.03 \pm 0.36 \mathrm{~cm})$ was the highest, while $C$. esculenta var. antiquorum $(3.70 \pm 0.96 \mathrm{~cm})$ was the least. The colour of the peeled raw tubers of all the varieties varied with C. esculenta var. antiquorum and Colocasia esculenta var. esculenta having the same colour (Table 1).

\section{Discussion}

The common leaf features of all the varieties with the exception of presence of foliaceous outgrowth at the abaxial surface of "ogeriobosi” suggested their inter-relatedness. These characters could be regarded as their field characters and probably as the generic characters of Colocasia; which some could be applicable in distinction of Colocasia from Xanthosoma. The appearance of C. esculenta and X. sagittifolium are sometimes confusing, as a result of their similarity. The leaves of Xanthosoma (Tannia) are large, approximately $20 \mathrm{~cm}$ in length, $15 \mathrm{~cm}$ in width, hastate (saggitate-ovate) in shape, with the anterior lobe twice as large as the posterior lobe, with distinct marginal vein, and round basal lobes [7]. In addition, the petiole attachment of Xanthosoma is at the margin of the leaf. Leaves of $X$. sagittifolium are nearly in a rosette in acaulescent plants, or in a distal crown in mature plants; blades horizontal to slight ascending, with the posterior lobes ascending, simple, upper surface dark green with light green primary secondary veins on basal lobes, lower surface light green with dark green venation; petioles light green; basal lobes of the leaf sub-rhomboid obtuse [8]. Colocasia can therefore, be easily distinguished from Xanthosoma by the point where the petiole is attached to the leaf. In Colocasia, the petiole attachment was peltate, whereas for Xanthosoma, the petiole attachment is at the margin of the leaf. Moreover, C. esculenta can be differentiated from $X$. sagittifolium by shape of the basal lobes, position of the leaf blades, and colour of petiole and leaf. In Colocasia esculenta, the basal lobe of leaf was round, leaf blade pointed downward, and leaf colour was dark green with petiole colour ranging from pale green, dark green, yellowish green and purple; while for $X$. sagittifolium, basal lobes is sub-rhomboid obtuse, blades horizontal to slight ascending, with leaf and petiole light green. It has been stated that morphological characteristics are the strongest determinants of the agronomic value and taxonomic classification of plants [9].

Generally, all the varieties of C. esculenta looked alike in the field until a closer look was made. Interestingly, however, there were remarkable differences in some parts of the varieties. Presence of foliaceous appendages at the veins of the abaxial surface of "ogeriobosi” leaves could be regarded as a diagnostic character; in addition, the leaf length of "ogeriobosi” (49.9 $\pm 3.55 \mathrm{~cm})$ was the highest; and deep purple colour of the petiole was the most conspicuous morphological feature differentiating it from others. Diagnostic character for "nwine" was possession of yellowish green petiole, with highest leaf width $(45.27 \pm 3.66 \mathrm{~cm})$, whereas that of "kochuo" was location of purplish spot in the centre of the adaxial surface of the leaves. In addition, varieties of $C$. esculenta can be delimited on the basis of their leaf, petiole as well as peeled corm and cormel colour. The leaves of $C$. esculenta var. esculenta, "kochuo" and "ogeriobosi” were deep green in colour, indicating a close relatedness, whereas those of $C$. esculenta var. antiquorum and "nwine” were pale green, also suggesting a close affinity. In addition, variation in the colour of the peeled raw corm and cormel of all the varieties with the exception of $C$. esculenta var. antiquorum and C. esculenta var. esculenta could be beneficial in differentiating them. The use of leaf characters in classification and identification of plants has been extensively reported. It has been documented that the leaf characters, such as arrangement, type, form, duration and venation are widely used in both classification and identification [10]. In Ulmus and Betula, the species are delimited only on the basis of leaf characters. In Trifolium, the species were separated on the basis of stipule morphology. Dalbergia species were distinguished on the basis of their leaflet, size, shape and arrangement on the rachis. The leaves are important for identification in palms, Salix and Populus [11]. Leaf character has been reported to be a critical tool in the hand of taxonomists in the classification and separation of taxa [12].

Moreover, there were some similarities between C. esculenta var. antiquorum and C. esculenta var. esculenta, which happened to be the only two taxonomically recognized varieties of $C$. esculenta. The colour of the peeled raw tubers of all the varieties varied, but $C$. esculenta var. antiquorum and C. esculenta var. esculenta had the same colour. There was also no significant difference in the leaf width of C. esculenta var. antiquorum (36.90 \pm $4.25 \mathrm{~cm})$ and C. esculenta var. esculenta $(36.00 \pm 2.65 \mathrm{~cm})$, indicating a close affinity between them. However, 
some morphological characters can be used in differentiating them. The corm and cormel length of $C$. esculenta var. esculenta $(6.17 \pm 0.50 \mathrm{~cm} ; 5.00 \pm 1.35 \mathrm{~cm})$ were bigger than those of $C$. esculenta var. antiquorum $(4.10 \pm$ $0.10 \mathrm{~cm} ; 3.70 \pm 0.96 \mathrm{~cm}$ ), respectively. Besides, $C$. esculenta var. antiquorum had large corm which was more or less orbicular (approximately, circular) in shape with numerous small round cormels, whereas the corm of $C$. esculenta var. esculenta was large and oval with few more or less cylindrical shaped cormels. The petiole of $C$. esculenta var. antiquorum was deep purple beneath, while C. esculenta var. esculenta was pale green. This suggested that the petiole colour, size, shape and number of corm and cormel of $C$. esculenta var. antiquorum and $C$. esculenta var. esculenta, therefore, were the most prominent morphological characters which distinguished them from each other. Some of these characters have extensively been used to differentiate between C. esculenta var. antiquorum and C. esculenta var. esculenta by various workers [2] [6] [13] [14].

There was also significant difference in the corm length, corm width and cormel length of all the varieties of C. esculenta. This indicated that these characters could be useful in distinguishing the varieties. Long slender cormel of "nwine" could be used as a ready distinctive character, as well as the largest corm and cormel size of "ogeriobosi”. It has been specified that underground parts, such as roots and tubers, are of some taxonomic value in plants [10]. The tubers are helpful in the taxonomy of Dioscorea and Cyperaceae. Some vegetative characters that play a major role in plant taxonomy and in deducing phylogeny include growth habit, phonological characters, underground organs, stems, leaves, petiole and stipules. Three sesame species, namely Sesamum alatum, S. radiatum and S. indicum were differentiated on the basis of their vegetative and the pod characteristics [15]. In addition, such characteristics, because of their high taxonomic importance, could be used in constructing a taxonomic key for the purpose of easy and quick identification of the three sesame species irrespective of their growth environment.

\section{Conclusions}

This work provided information on the morphology of these five varieties of C. esculenta present in Anambra State, Nigeria; which was previously lacking. Secondly, the overwhelming evidence from this study suggested close relatedness between C. esculenta var. antiquorum and C. esculenta var. esculenta, and provided diagnostic characters for "kochuo", "nwine" and "ogeriobosi".

Conspicuous diagnostic characters observed in "kochuo", were presence of purplish colour at the point of attachment to the leaf of the abaxial leaf surface, as well as presence of a purplish dot on the centre of the adaxial surface of the leaf, and numerous vertical purplish stripes on the surface of the cormels. For "ogeriobosi", the prominent diagnostic features include: presence of foliaceous appendages at the veins of the abaxial surface of the leaves, as well as the purplish colour of the petiole; while yellowish green petiole colour of "nwine" was only the striking diagnostic character. The differential characters include, large corm of $C$. esculenta var. antiquorum, which was more or less orbicular (approximately circular) in shape with numerous small round cormels; large and oval corm of $C$. esculenta var. esculenta with few more or less cylindrical shaped cormels; slender cormels of "nwine"; and possession of the largest oval corm of "ogeriobosi".

Plants are generally grouped by their relationship to one another based on their similarities and differences, which is based on the characters they possess. This study, therefore, supplied additional morphological information which might be helpful in resolving the on-going controversy in the taxonomy of Colocasia, which would, in turn, probably lead to possible delimitation of $C$. esculenta.

\section{References}

[1] Aiyeloja, A.A. and Bello, O.A. (2006) Ethnobotanical Potentials of Common Herbs in Nigeria: A Case Study of Enugu State. Educational Research and Review, 1, 16-22.

[2] Nyananyo, B.L. (2006) Plants from the Niger Delta. Onyoma Research Publications, Port Harcourt, 403 p.

[3] Okujagu, T.F. (2008) Medicinal Plants of Nigeria; South East Zone, Vol. 1. Lisida Consulting, Lagos, 204 p.

[4] United States Department of Agriculture (2013) Taxon: Colocasia esculenta (L.) Schott. National Germplasm Resources Laboratory, Beltsville, 5 p.

[5] Gomez-Beloz, A. and Rivero, T. (2006) Ure (Colocasia esculenta Araceae): An Edible Aroid of the Warao. Ethnobotany Research and Applications, 4, 103-111.

[6] Brooks, F. (2001) Crop Profile for Taro in American Samoa. ASCC Land Grant Program, Pago, 15 p. 
[7] Manner, H.I. (2011) Farm and Forestry Production and Marketing Profile for Tannia (Xanthosoma spp.). In: Elevitch C.R., Ed., Specialty Crops for Pacific Island Agroforestry, Permanent Agriculture Resources (PAR), Holualoa, 1-16.

[8] Acevedo-Rodriguez, P. and Strong, M.T. (2005) Monocots and Gymnosperms of Puerto Rico and Virgin Islands. Contribution from the United National Herbarium, Volume 52, 1-415.

[9] Cholastova, T. and Knotova, D. (2012) Using Morphological and Microsatellite (SSR) Markers to Assess the Genetic Diversity in Alfalfa (Medicago sativa L.). World Academy of Science, Engineering and Technology, 69, 856-862.

[10] Sharma, O.P. (1993) Plant Taxonomy. Tata McGraw-Hill Publishing Company Limited, New Delhi, 482 p.

[11] Singh, G. (2004) Plant Systematics. 3rd Edition. Oxford IDH Publishing Co Pvt. Ltd., New Delhi, 598 p.

[12] Illoh, H.C., Oladipo, O.T. and Adedeji, A.A. (2011) Comparative Systematic Foliar Morphological and Anatomical Studies of Three Cleome (Linn.) Species in Nigeria. Nigerian Journal of Botany, 24, 17-42.

[13] Udealor, A. and Ezulike, T.O. (2011) Evaluation of Different Crop Species for Compatibility with Cocoyam Minisett. Nigerian Journal of Plant Protection, 25, 122-129.

[14] Ugwuaja, F.N. and Chiejina, N.V. (2011) Preliminary Investigation of the Causes of Leaf Rot of Cocoyam in Nsukka Zone of Nigeria. Nigerian Journal of Plant Protection, 25, 203-213.

[15] Alege, G.O., Akinyele, B.O., Ayodele, S.M. and Ogbode, A.V. (2011) Taxonomic Importance of the Vegetative and Pod Characteristics in Three Nigerian Species of Sesame. African Journal of Plant Science, 5, 213-217. 